\title{
Sağlık Sektöründe Tedarikçi Seçim Kararının AHP Yöntemi İle İncelenmesi: Bir Üniversite Hastanesi Örneği
}

\author{
Nuri Özgür Doğan a,b, Hazal Akbal c
}

Özet

Anahtar Kelimeler

Hastaların teşhis, muayene ve tedavi işlemlerinde kullanılan medikal malzemeler sağlık kurumları için hayati önem arz etmektedir. Hastalar için ihtiyaç duyulan bu malzemelerin temininde etkin, doğru ve yerinde kararlar verilmesi gerekmektedir. Hastaneler malzeme tedarikçilerini seçerken belirli kanun ve yönetmeliklere uygun bir şekilde karar vermek zorundadırlar. Ancak hastanelerin çok fazla sayıda tedarikçisi bulunduğundan dolayı kanun ve yönetmeliklerce belirlenen çeşitli kriterler çerçevesinde karar vermek zorlaşmaktadır. Bu çalışmada hem hasta hem de hastane açısından en uygun tedarikçi seçim kararının verilebilmesi için çok kriterli karar verme yöntemlerinden biri olan AHP yöntemi kullanılmıştır. Çalışma Niğde ilinde faaliyet gösteren bir üniversite hastanesinin satın alma birim yöneticilerinin bakış açısıyla medikal firmalar arasından en uygun tedarikçinin seçilmesi amacıyla yapılmıştır. Çalışmanın sonunda bir üniversite hastanesi için medikal firma seçiminde etkili olan kriterler belirlenmiş ve bu kriterler medikal firmalar arasında karşılaştırılarak bir sonuca varılmıştır.

\section{Investigation of the Supplier Selection Decision by the AHP Method in the Healthcare Sector: A Case of a University Hospital}

\section{Abstract}

The medical supplies used in the diagnosis, examination and treatment of patients are vital for healthcare organizations. Efficient, accurate and appropriate decisions must be made in the supply of materials that patients need. Hospitals must make decisions in accordance with certain laws and regulations when selecting material suppliers. However hospitals have a large number of suppliers and this makes it difficult to choose the appropriate one among them while taking into consideration the various criteria determined by laws and regulations. In this study, the AHP method which is one of the multiple criteria decision making methods was used to determine the most appropriate supplier decision for both patient and hospital. The study was conducted in the purchasing department of a university hospital in Niğde with the aim of selecting the most suitable suppliers among the medical companies from the point of view of the managers. At the end of the study, the criteria for selecting a medical company for a university hospital were determined and these criteria have been compared among the medical companies and a result

has been achieved.
Analitik Hiyerarşi Prosesi

Sağlık Sektörü

Tedarikçi Seçimi

Medikal Firma

Makale Hakkında

Geliş Tarihi: 25.06.2018

Kabul Tarihi: 05.11.2019

Doi: 10.18026/cbayarsos.664380

a N. Özgür DOĞAN, nodogan@nevsehir.edu.tr

b Doç. Dr., Nevşehir Hacı Bektaş Veli Üniversitesi İktisadi İdari Bilimler Fakültesi, nodogan@nevsehir.edu.tr, ORCID NO 0000-0002-7892-1550

c Öğr. Gör. Niğde Ömer Halisdemir Üniversitesi Zübeyde Hanım Sağlık Hizmetleri MYO, hazalakbal@ohu.edu.tr, ORCID NO 0000-0002-51299777 


\section{Giriş}

Sağlık sektörü içerisinde hizmet sunumunda aktif olarak görev alan farklı ve çok sayıda sağlık kuruluşu yer almaktadır. Bu sağlık kuruluşlarının pazardaki payını artırabilmek ve rakiplerine karşı ayakta kalabilmek için hizmet satın alanların değişen ihtiyaç ve beklentilerine cevap verebilmeleri gerekmektedir. Sağlık kuruluşları, hizmet satın alanlara kaliteli sağlık hizmeti sunabilmek için tıbbi malzeme, büro malzemesi, yiyecek, 1sıtma ve diğer malzemeler gibi çeşitli malzemelere ihtiyaç duymaktadır. Özellikle ihtiyaç duyulan tıbbi malzemelerin zamanında tedarik edilmesi hem hizmeti sunan sağlık kuruluşu hem de hizmeti satın alan kişiler tarafından büyük önem taşımaktadır.

Çalışma yapılan sağlık kuruluşu eğitim, öğretim ve araştırma hizmetlerinin sunulduğu bir üniversite hastanesidir. Hastane birinci ve ikinci basamak sağlık kuruluşlarında tedavi edilmeyen hastalara hizmet sunulmaktadır. Bu hastanede tıp, sağlık bilimleri fakültesi ve meslek yüksekokulu öğrencileri başta olmak üzere birçok öğrenci uzmanlık eğitimi almaktadır. Hastane karmaşık hastalıkların tedavisinde rol aldığı için herhangi bir malzeme yokluğu, hizmet satın alan kişilerde ciddi sonuçlar ortaya çıkarabilecektir. Bu nedenle demirbaş, mefruşat, giyim, teknik bakım ve onarım malzemeleri ile tıbbi sarf malzemelerinin tedarik edildiği medikal firmaların seçimi son derece önemlidir. Hastalar için ihtiyaç duyulan bu malzemelerin temininde etkin, doğru ve yerinde kararlar verilmesi gerekmektedir.

$\mathrm{Bu}$ çalışmanın amacı, çok kriterli karar verme yöntemlerinden biri olan AHP yöntemi yardımıyla Niğde ilinde faaliyet gösteren bir üniversite hastanesinin medikal malzeme tedarikçileri arasından en uygun tedarikçinin seçilmesidir.

Çalışmanın geriye kalan kısımları şu şekilde tasarlanmıştır: İkinci bölümde sağlık sektöründe tedarik zinciri yönetimi ve satın alma sürecine yer verilerek tedarikçi seçim kriterleri ve tedarik zinciri üyeleri hakkında bilgi verilmiştir. Üçüncü bölümde çeşitli sektörlerde araştırmalara konu olan AHP yöntemi ile ilgili literatür taramasına yer verilmiştir. Dördüncü bölümde çalışmanın metodolojisi hakkında bilgiler verilmiş olup beşinci bölümde çalışmadan elde edilen bulgular yorumlanmıştır. Çalışma genel bir değerlendirmenin yapıldığı sonuç bölümü ile bitirilmektedir.

\section{Sağlık Sektöründe Tedarik Zinciri ve Satın Alma Süreci}

Tedarik zinciri ham maddeden tüketiciye doğru ilerleyen uzun bir yolculuktur. Bir ürün için gerekli olan ham maddenin temini, bu maddelerin üretim tesislerine getirilmesi, maddelerin üretime girmesi, nihai müşteriye ulaşması, atıkların toplanması ve iadelerin değerlendirilmesine kadar olan faaliyetler bütünü tedarik zinciri olarak adlandırılmaktadır (Nebol, 2016).

\section{Sağlık Sektöründe Satın Alma ve Tedarik Zinciri Üyeleri}

Sağlık sektörü açısından tedarik zinciri yönetimi, malzemenin üretim aşamasından hastaya ulaşana kadar geçen süreçlerin uyum içerisinde olmasının sağlanmasında ürünlerin ve bilginin akışını yöneten bütünleşik bir sistemdir. Sağlık sektöründe tedarik zinciri üyeleri ilaç ve farmasötik üreticileri, tıbbi cihaz üreticileri, medikal ve cerrahi malzeme üreticileri, 
distribütörler, toptancılar, perakendeciler, hizmet sunucular, eczaneler, kamu ve özel sağlık kuruluşları ile ortak satın alma kuruluşlarından oluşmaktadır (Tengilimoğlu \& Yiğit, 2013).

Sağlık kurumları çeşitli yönetmelik standartlarıyla çalıştı̆̆ından ilaç, tıbbi cihaz ve malzemelerin temin edilmesi ve kurumların hizmetlerini aksatmadan sürdürebilmesi için ihtiyaçların karşılanması karmaşık bir hâle gelmiştir (Bayar, 2008). Son yıllarda sağlık kurumları hizmet maliyetini düşürmek, israfı azaltmak, tıbbi hataları önlemek, hizmet kalitesini yükseltmek ve operasyonel verimliliği artırmaya yönelik baskının artması sebebiyle sağlık sektöründe tedarik zinciri yönetimine önem vermeye başlanmıştır (Byrnes, 2004).

Ülkemizde kamu sağlık kurumlarında ihtiyaç duyulan malzeme ve teçhizatların alımında çeşitli kanun, yönetmelik ve genelgelerden faydalanarak satın alım işlemleri gerçekleşmektedir. 4734 sayılı Kamu İhale Kanunu kamu kurumlarında yapılacak olan ihalelerde uygulanacak olan usul ve esasları belirlemektedir. Kanun'un 18. maddesinde yer alan açık ihale usulü, pazarlık usulü, belli istekliler arasında ihale usulü ve doğrudan temin usulleri ile satın alım işlemleri gerçekleşmektedir. 4734 sayılı Kamu İhale Kanunu'nda belirtilen esasların doğru olarak uygulanması için Elektronik Kamu Alımları Platformu (EKAP) geliştirilmiştir (KIK, 2002: ek md.1). Sağlık Bakanlığına bağlı hastanelerin tıbbi sarf malzemesi, ilaç, serum, aşı, ortez, protez gibi malzeme ihtiyaçları çerçeve ve toplu satın alımlarla kamu hastane birlikleri genel sekreterliği birimince merkezden karşılanmaktadır. Çerçeve Anlaşmalar ve Toplu Alımlar Genelgesi'ne göre Sağlık Bakanlığına bağlı döner sermayeli kurumların, döner sermaye kaynaklarından yapacakları alımlarda kaynaklarını daha etkin ve verimli kullanmalarını, ihtiyaçlarını zamanında ve daha ekonomik karşılamalarını sağlayabilmeleri amacıyla, 2010 yılı ve sonrası ihtiyaçları için yapacakları tıbbi sarf malzemesi, ilaç, serum, anti serum, aşı, ortez, protez gibi alımlarında il düzeyinde toplu olarak yapılacak çerçeve anlaşmaların uygulanması zorunlu tutulmuştur (Çerçeve Anlaşmalar ve Toplu Alımlar Genelgesi, 2011). Ayrıca sağlık kurumları Devlet Malzeme Ofisinden (DMO) demirbaş, dayanıklı tüketim ve sarf malzemeleri gibi çeşitli malzeme gruplarını tedarik edebilmektedir.

Sağlık kurumlarının faaliyetlerini gerçekleştirmesinde hayati öneme sahip malzemelerin tedarik edilebilmesi için çeşitli kriterler 1şığında doğru ve etkin tedarikçinin seçilmesi önemlidir.

\section{Tedarikçi Seçim Süreci ve Kriterleri}

Sağlık hizmet sunumunda görev alan sağlık kuruluşları için tedarikçi seçimi özenle üzerinde durulması gereken bir konu hâline gelmiştir. Sağlık kuruluşlarında kritik rol oynayan malzemelerin yokluğu hizmet satın alacak olan kişilerin sağlıklarını doğrudan etkileyecek ve geri dönüşü olmayan kayıplara neden olacaktır. Bu nedenle doğru tedarikçi seçimi etkin bir tedarik zinciri yönetiminin kilit noktasıdır.

Tedarikçilerin seçimi konusunda yaşanılan tecrübelerden yararlanılabileceği gibi tedarikçilerden alınan fiyat listeleri, broşürler, kataloglar ve reklamlardan da faydalanılabilir (Yenersoy, 1990).

Tedarikçi seçimi konusunda yapılan ilk kapsamlı çalışma 1966 yılında Dickson tarafından Amerika'da yapılmıştır. Dickson, satın alma acentesi ve ulusal satın alma derneği 
yöneticilerinden seçilen 273 kişiye anket göndermiş ve bu ankette 23 kriter kullanılmıştır. Bu kriterler kalite, teslimat, performans geçmişi, garanti ve şikayet politikası, üretim yetenekleri kapasitesi, fiyat, teknik kapasite, finansal pozisyon, prosedürlere uyum, iletişim sistemi, ün ve endüstrideki pozisyonu, iş yapma isteği, yönetim ve organizasyon, operasyon kontrol, onarım servisleri, davranış, etki, paketleme kabiliyeti, işçi ilişkileri kayıtları, coğrafi konum, geçmiş iş tutarı, eğitim yardımları ve karşılıklı düzenlemelerdir (Dickson, 1966).

Tedarikçi seçim süreci tedarikçi seçimiyle elde edilmek istenen durumun tanımlanması aşaması ile başlayıp, seçim kriterlerinin belirlenerek potansiyel tedarikçiler arasından ön elemenin yapılması ve seçim kriterlerine uyan tedarikçiler arasından son seçimin yapılması şeklinde ortaya çıkmaktadır (Bayhan, 2011). Bu süreçte karar verirken kullanılacak kriterler hem sektör hem de tedarikçiler için uygun, sağlık kuruluşunun ihtiyacını karşılayacak nitelikte olmalıdır.

\section{Literatür}

Analitik Hiyerarşi Prosesi (AHP) “Thomas L. Saaty tarafından 1977 yılında geliştirilmiştir. Yöntem, en genel tanımıyla, çoklu kriter ve önem düzeylerinin belirlenmesinde yapısal bir yaklaşım sağlamaktadır." (Eleren, 2007). AHP yöntemi birçok farklı konu ve sektörde uygulama alanı bulmuştur; ormancılık (Kurttila vd., 2000), elektrik-elektronik (Sambasivan \& Fei, 2008) e-ticaret (Lee \& Kozar, 2006), iş sistemleri güvenliği (Dağdeviren \& Yüksel, 2008), performans iyileştirme (Albayrak \& Erensal, 2004), akıllı bina sistemlerinin seçimi (Wong \& Li), teknoloji yol haritası geliştirimi (Gerdsri \& Kocaoğlu, 2007), tesis konumu belirleme (Badri, 1999; Chou vd., 2008; Aydın vd., 2009; Alp \& Gündoğdu, 2012; Soba, 2014), marka seçimi (Eleren, 2007); iş değerlendirme (Dağdeviren vd., 2004), malzeme seçim kararı (Cihan vd., 2017) tedarik zinciri yönetimi (Korpela vd., 2001), turizm merkezi seçimi (Manap, 2006; Adıgüzel vd., 2009) ve hastane seçimi (Gupta, 2015) gibi çeşitli sektör ve konularda kullanım aracı olmuştur.

AHP birçok alanda olduğu gibi tedarikçi seçimi ve değerlendirilmesi konusunda da çeşitli araştırmalarda yer almıştır. Çok kriterli karar verme tekniklerinden biri olan AHP ile tedarikçi seçimi, imalat sektörü (Soner \& Önüt, 2006; Tahriri vd., 2008), perakende sektörü (Akdeniz \& Turgutlu, 2007), turizm sektörü (Davras \& Karaatll, 2014), otomotiv sektörü (Özyörük \& Özcan, 2008; Bali \& Amin, 2017), sağlık sektörü (Vatansever, 2013; Yadav vd., 2015; Malik vd., 2016; Asadi vd., 2018) yeşil işletmecilik (Handfield vd., 2002) ve biyoenerji endüstrisi (Ghodsypour \& Brien, 1998) gibi sektörlerde araştırma alanı olmuştur.

Tablo 1'de AHP yöntemi ile farklı alanlarda ve sektörlerde tedarikçi seçiminde belirlenen tedarikçi kriterleri özetlenmiştir: 
Tablo 1. AHP İle Tedarikçi Seçiminde Belirlenen Kriterler

\begin{tabular}{|c|c|c|}
\hline Yazar & Çalışma Konusu ve Alanı & Önemli Tedarikçi Kriterleri \\
\hline $\begin{array}{l}\text { Ghodsypour \& } \\
\text { Brien, } 1998\end{array}$ & $\begin{array}{l}\text { Biyoenerji endüstrisinde } \\
\text { tedarikçi seçimi }\end{array}$ & $\begin{array}{l}\text { Uzun süreli sözleşmeler, parça kaydı, kişisel ilişkiler, } \\
\text { sabit fiyat, tedarikçi istikrarı, kalite kontrol } \\
\text { mekanizması, çevre düzenleyici ortam, finansal } \\
\text { olarak } \\
\text { sağlam ve güvenilir olmak, en iyi biyokütle kullanımı }\end{array}$ \\
\hline $\begin{array}{l}\text { Handfield vd., } \\
2002\end{array}$ & $\begin{array}{l}\text { Çevresel kriterlerin tedarikçi } \\
\text { değerlendirmesinde kullanımı }\end{array}$ & $\begin{array}{l}\text { Ürün özellikleri, Atık yönetimi, Belgelendirme, } \\
\text { Ambalajlama/tersine lojistik, Devletin yasalarına } \\
\text { destek vermek, Çevresel programlar }\end{array}$ \\
\hline $\begin{array}{l}\text { Soner \& Önüt, } \\
2006\end{array}$ & $\begin{array}{l}\text { Havalandırma ve klima üreten } \\
\text { bir firmada tedarikçilerin } \\
\text { değerlendirilmesi }\end{array}$ & $\begin{array}{l}\text { İş masrafları, Ortalama masraf maliyetleri, Mesafe, } \\
\text { Ömür, Teknoloji kullanımı, Hız, Kalite }\end{array}$ \\
\hline $\begin{array}{l}\text { Akdeniz \& } \\
\text { Turgutlu, } 2007\end{array}$ & $\begin{array}{l}\text { Perakende sektöründe } \\
\text { tedarikçi performansının } \\
\text { değerlendirilmesi }\end{array}$ & $\begin{array}{l}\text { Brüt kâr, Satış tarihçesi, Teslimat Kalite, Pazar } \\
\text { hâkimiyeti , Hizmet }\end{array}$ \\
\hline $\begin{array}{l}\text { Tahriri vd., } \\
2008\end{array}$ & $\begin{array}{l}\text { Çelik eşya imalat sektöründe } \\
\text { tedarikçilerin } \\
\text { değerlendirilmesi }\end{array}$ & Fiyat, Kalite, Ustalık, Teslimat \\
\hline $\begin{array}{l}\text { Özyörük \& } \\
\text { Özcan,2008 }\end{array}$ & $\begin{array}{l}\text { Otomotiv sektöründe tedarikçi } \\
\text { seçimi }\end{array}$ & $\begin{array}{l}\text { Ürün kalitesi, Teslim tarihine uyum, Sipariş miktarına } \\
\text { uyum, Siparişteki ürün özelliklerine uyum, Sorunlara } \\
\text { yaklaşım }\end{array}$ \\
\hline $\begin{array}{l}\text { Vatansever, } \\
2013\end{array}$ & $\begin{array}{l}\text { Ameliyat malzemesi alım } \\
\text { kararlarında tedarikçi seçimi }\end{array}$ & $\begin{array}{l}\text { Kalite, Maliyet, Kullanım kolaylığı, Kullanım ömrü, } \\
\text { Ürün ham maddesi, Yedek parça garantisi }\end{array}$ \\
\hline $\begin{array}{l}\text { Davras \& } \\
\text { Karaatlı, } 2014\end{array}$ & $\begin{array}{l}\text { Otel işletmelerinde tedarikçi } \\
\text { seçimi }\end{array}$ & $\begin{array}{l}\text { Fiyat, Güvenilirlik, Ürün kalitesi, Teslimat } \\
\text { performansı, Ödeme kolaylığı, Referans }\end{array}$ \\
\hline $\begin{array}{l}\text { Yadav vd, } \\
2015\end{array}$ & Eczanelerde tedarikçi seçimi & $\begin{array}{l}\text { Kalite, Tedarikçi profili, Risk yönetimi, Maliyet, } \\
\text { Hizmet }\end{array}$ \\
\hline $\begin{array}{l}\text { Malik vd., } \\
2016\end{array}$ & $\begin{array}{l}\text { Sağllk zincirinde tedarikçinin } \\
\text { çevresel faktöre göre seçimi }\end{array}$ & $\begin{array}{l}\text { Ürün özellikleri, Çevresel ayak izi, Gönüllü } \\
\text { sertifikalar, Kalite güvencesi, Kaynak tüketimi, Yasal } \\
\text { uyumluluk yetkinliği, Tedarik zinciri yönetimi, } \\
\text { Tedarik zinciri uygulamaları }\end{array}$ \\
\hline $\begin{array}{l}\text { Bali \& Amin, } \\
2017\end{array}$ & $\begin{array}{l}\text { Otomobil parçası üreten } \\
\text { işletmede tedarikçi seçimi }\end{array}$ & $\begin{array}{l}\text { Kalite, Teslimat, Teslimat süresi, Hizmet, Fiyat, } \\
\text { Uzaklık }\end{array}$ \\
\hline Asadi vd, 2018 & $\begin{array}{l}\text { Hastanelerin dış kaynak } \\
\text { hizmetlerinde görevli } \\
\text { tedarikçilerin seçimi }\end{array}$ & $\begin{array}{l}\text { Hizmet kalitesi, Yönetim sistemleri, Müşteri } \\
\text { hizmetleri, Bilgi güvenliği, Coğrafi konum, Esneklik, } \\
\text { Problem çözme }\end{array}$ \\
\hline
\end{tabular}

Çalışma sağlık sektörünün en önemli uygulama alanlarından biri olan hastaneler üzerinde yürütülmüştür. Çalışmanın Niğde ilinde faaliyet gösteren medikaller ile sınırlı tutulması, tedarikçilerin hastanenin en fazla alım yaptığı medikal firmalardan oluşması ve satın alma sorumlularının bakış açısı ile değerlendirilmesi açısından literatürdeki diğer çalışmalardan ayrilmaktadir. 


\section{Yöntem}

Çalışma, değerlendirme kriterlerini karşılayan ve yalnızca Niğde ilinde faaliyet gösteren toplam 10 adet medikal firma içerisinden hastanenin en sık alım yaptığ 4 medikal firma ile sınırlı tutulmuştur. Medikal firmalar arasından en uygun tedarikçiye ilişkin kriterler belirlenirken hastanenin satın alma birim yöneticisi ve çalışanları ile yüz yüze görüşme ve mülakat yapılmış olup onların bilgi ve deneyimlerinden faydalanılmıştır. Görüşmecilerden Dickson'ın 23 maddeden oluşan tedarikçi değerlendirme unsurları 1şığında en uygun kriterleri belirlemeleri istenmiştir. Belirlenen kriterler; Tablo 2' de belirtildiği gibi fiyat, teknik yeterlilik, hizmet kalitesi, tamir hizmeti ve garanti politikasıdır.

Tablo 2. Tedarikçi Değerlendirme Kriterleri

\begin{tabular}{|c|c|}
\hline KRITTERLER & AÇIKLAMA \\
\hline Fiyat & En ekonomik malzeme fiyatıdır. \\
\hline Teknik yeterlilik & $\begin{array}{l}\text { Tedarikçi firmanın işi yapmaya vakıf olmasıdır. Araştırma geliştirme faaliyetleri } \\
\text { doğrultusunda yenilikleri takip etmeyi ve kendini geliştirmeyi ifade etmektedir. }\end{array}$ \\
\hline Hizmet kalitesi & $\begin{array}{l}\text { Firmanın hastaneye sunduğu hizmetin kalitesidir. Çalışanların tutum ve } \\
\text { davranışları, iletişim, güvenlik, firmanın hizmeti bir kerede ve doğru sunması, } \\
\text { firmaya istenildiği her an ulaşılabilmesi gibi hizmetleri ifade etmektedir. }\end{array}$ \\
\hline Tamir hizmeti & $\begin{array}{l}\text { Tedarikçi firmanın sunduğu malzeme ve teçhizatlara ilişkin düzenli kontrol, } \\
\text { bakım ve tamir hizmetlerinin sunulmasıdır. }\end{array}$ \\
\hline Garanti politikası & Tedarikçi firmanın sattığı malzemelere ilişkin belirli garanti süreleridir. \\
\hline
\end{tabular}

\section{Analitik Hiyerarşi Prosesi}

AHP ilk olarak 1968 yılında Myers ve Alpert ikilisi tarafından ortaya atılarak 1977 y1lında Thomas Lorie Saaty tarafından bir model olarak geliştirilerek karar verme problemlerinin çözümünde kullanılır hâle getirilmiştir (Yaralığlu, 2001). AHP, çoklu kriterler içerisinden en iyi alternatifi seçmeye yarayan bir karar verme yöntemidir. Karar verme aşamasında çok kriterli karar verme yöntemlerinin kullanılması alternatifleri değerlendirme konusunda fayda yaratarak işletme kaynaklarının daha verimli kullanılmasını sağlamaktadır. Bu yöntemler ölçülebilen ve ölçülemeyen birçok stratejik ve operasyonel faktörü aynı anda değerlendirme imkânı sağlayan, aynı zamanda karar verme sürecine çok sayıda kişiyi dâhil edebilen bir analitik yöntemdir (Ömürbek \& Şimşek, 2014).

AHP'nin en önemli özelliği karar vericinin hem öznel hem de nesnel olarak karar sürecine dahil olabilmesidir. Yani AHP bilginin, deneyimin, bireyin düşüncelerinin ve önsezilerinin mantıksal bir şekilde birleştirildiği bir yöntemdir (Kuruüzüm \& Atsan, 2001).

AHP uygulamasına başlarken öncelikle karar problemi Şekil 1'de görüldüğü gibi hiyerarşik bir yapıya dönüştürülür. Hiyerarşinin en üstünde nihai amaç yer almaktadır. Amacın alt kısmında amaca ulaşmak için kullanılan kriterler ve en altta alternatiflere yer verilmektedir (Ömürbek \& Şimşek, 2014). 


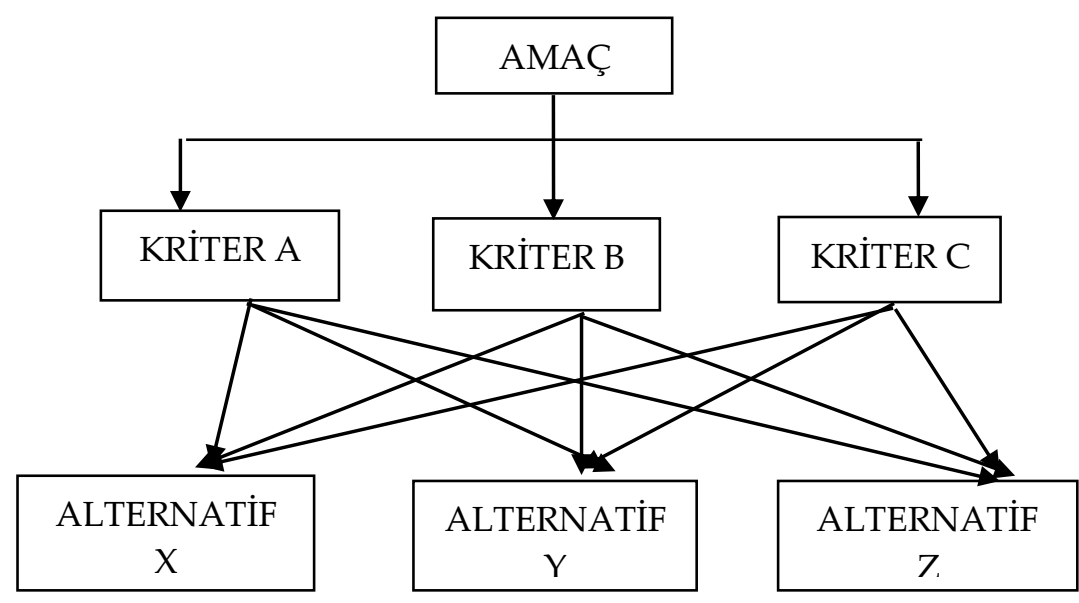

Şekil 1. AHP'nin Hiyerarşik Yapısı

Kaynak. Ömürbek \& Şimşek, 2014.

AHP uygulamasının ikinci aşamasında hiyerarşik yapı oluşturulduktan sonra kriterlerin kendi aralarında karşılaştırılması ve her bir kriter açısından alternatiflerin karşılaştırılması için ikili karşılaştırma matrisleri oluşturulur. Bu matrislerin oluşturulmasında Tablo 3'te gösterilen Saaty tarafından önerilen 1-9 önem ölçeği kullanılır. Ölçekte yer almayan 2, 4, 6, 8 değerleri ara değerlerdir. Örneğin karar verici 1 ve 3 arasında kararsız kalırsa 2 değerini kullanabilir (Dağdeviren \& Eren, 2001).

Tablo 3. AHP'de Kullanılan Önem Ölçeği

\begin{tabular}{ll}
\hline Önem Derecesi & Tanımı \\
\hline 1 & Eşit önemli \\
3 & Orta derecede önemli \\
5 & Kuvvetli derecede önemli \\
7 & Çok kuvvetli derecede önemli \\
9 & Kesin önemli \\
$2,4,6,8$ & Ara değerler \\
\hline
\end{tabular}

Kaynak: Dağdeviren \& Eren, 2001.

Üçüncü aşama olan normalleştirme işleminin gerçekleştirilmesi için tüm sütun değerleri her bir matris sütununun toplamına bölünür. Normalleştirilmiş matris kullanılarak her bir satır değerinin ortalaması alınarak elde edilen değerler, her bir kriter için yüzde önem ağırlık değerleridir (Toksarı, 2007).

Dördüncü aşama karar vericilerin kriterler arasında kıyaslama yaparken tutarlı olup olmadıklarını ölçmek için tutarlılık oranının (TO) hesaplandığı aşamadır. Tutarlılık oranı hesaplanırken karşılaştırma matrisinin sütunları ile öncelik değerleri çarpılarak toplanır. Böylelikle ağırlıklı toplam vektör (ATV) oluşturulur. Daha sonra ATV elemanları kendisine karşılık gelen öncelik değerlerine bölünür. Elde edilen sonuçların ortalaması alınarak $\lambda$ max değeri bulunur. $\lambda \max$ bulunduktan sonra yapılacak olan işlem tutarlılık indeksini (TI) hesaplamaktır. Tutarlılık indeksi şu şekilde hesaplanmaktadır (Doğan \& Gencan, 2013): 
$\mathrm{TI}=(\lambda \max -\mathrm{n}) /(\mathrm{n}-1)$

Burada n; ilgili ikili karşılaştırma matrisinde yer alan kriter ve/veya alternatiflerin sayısıdır.

Tİ bulunduktan sonra tutarlık oranı da şu şekilde hesaplanmaktadır:

$\mathrm{TO}=\mathrm{TI} / \mathrm{RI}$

Rİ değeri Rassal İndeks değeridir. Tablo 4'te verilen Rassal İndeks tablosundan uygun değer seçilerek işlem yapılır. Elde edilen tutarlık oranı 0,10'dan küçükse yapılan karar verme işlemi tutarlı olup kararlar uygulanır (Uzun \& Kazan, 2016).

Tablo 4. Rassal İndeks Değeri

\begin{tabular}{|c|c|c|c|c|c|c|c|c|c|c|c|c|c|c|c|}
\hline $\mathrm{n}$ & 1 & 2 & 3 & 4 & 5 & 6 & 7 & 8 & 9 & 10 & 11 & 12 & 13 & 14 & 15 \\
\hline RI & 0 & 0 & 0.52 & 0.89 & 1.12 & 1.25 & 1.35 & 1.40 & 1.45 & 1.49 & 1.52 & 1.54 & 1.56 & 1.57 & 1.59 \\
\hline
\end{tabular}

Kaynak. Saaty \& Tran, 2007.

AHP uygulamasının son aşaması ise nihai öncelik değerlerinin hesaplanmasıdır. Bu aşamada kriterlerin öncelik değerleri ile alternatiflerin öncelik değerleri çarpılır ve her bir alternatife ait öncelik değeri bulunur. En yüksek değere sahip alternatif, karar problemi için en iyi alternatiftir (Toksarı, 2007).

\section{Bulgular}

Çalışma Niğde ilinde faaliyet gösteren bir üniversite hastanesinin satın alma birim yöneticilerinin bakış açısıyla medikal firmalar arasından en uygun tedarikçinin seçilmesi amacıyla satın alma departmanında 2018 yılının Nisan ayında gerçekleştirilmiştir. Çalışmanın yapıldığı sağlık kurumu bir üniversite hastanesi olup tıp, sağlık bilimleri fakültesi ve meslek yüksekokulu öğrencileri başta olmak üzere birçok öğrenciye uzmanlık eğitimi vermektedir.

Çalışma yapılan hastane, isminin gizli tutulmasını istediğinden ve medikal firma isimlerinin açıkça belirtilmesinin rekabeti engelleyeceği düşünüldüğünden isimler açıkça verilmemiştir. Bu firmalar Medikal X, Medikal Y, Medikal Z ve Medikal T olarak adlandırılmıştır. Bu dört alternatif medikal firma ve beş kriterin değerlendirildiği hiyerarşik yapı Şekil 2'de gösterilmiştir. 


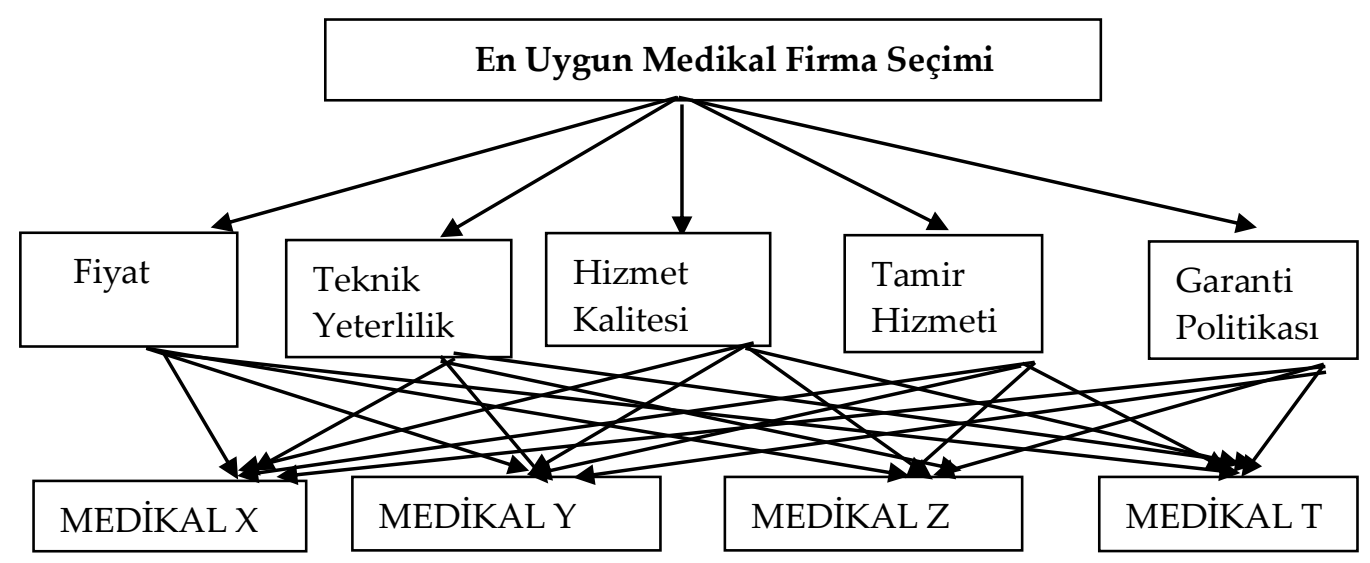

Şekil 2. AHP’nin Uygulamadaki Hiyerarşik Yapısı

En uygun medikal firma seçim kararı için satın alma birim yöneticisi ve çalışanları tarafından Dickson'ın 23 maddeden oluşan tedarikçi değerlendirme unsurları ışığında en uygun kriterler belirlenmiştir. Daha sonra Saaty tarafından geliştirilen önem ölçeği doğrultusunda kriterler önem sırasına göre karşılaştırılmıştır. Belirlenen kriterler için Tablo 5 'te belirtildiği gibi karşılaştırma matrisleri oluşturulmuştur.

Tablo 5. Kriterlerin İkili Karşılaştırılması

\begin{tabular}{llllll}
\hline Kriterler & Fiyat & Teknik Yeterlilik & Hizmet kalitesi & Tamir Hizmeti & Garanti Politikasi \\
\hline Fiyat & 1,000 & 3,000 & 4,000 & 7,000 & 8,000 \\
$\begin{array}{l}\text { Teknik } \\
\text { Yeterlilik }\end{array}$ & 0,333 & 1,000 & 2,000 & 5,000 & 6,000 \\
$\begin{array}{l}\text { Hizmet } \\
\text { Kalitesi }\end{array}$ & 0,250 & 0,500 & 1,000 & 3,000 & 4,000 \\
$\begin{array}{l}\text { Tamir } \\
\text { Hizmeti }\end{array}$ & 0,142 & 0,200 & 0,333 & 1,000 & 3,000 \\
$\begin{array}{l}\text { Garanti } \\
\text { Politikasi }\end{array}$ & 0,125 & 0,166 & 0,250 & 0,333 & 1,000 \\
Toplam & $\mathbf{1 , 8 5 0}$ & $\mathbf{4 , 8 6 6}$ & $\mathbf{7 , 5 8 3}$ & $\mathbf{1 6 , 3 3 3}$ & $\mathbf{2 2 , 0 0 0}$ \\
\hline
\end{tabular}

İkili karşılaştırma matrisinden sonra normalleştirme işlemini gerçekleştirilmiştir. Normalleştirme işleminde tüm sütun değerleri her bir matris sütununun toplamına bölünmüştür. Normalleştirilmiş matris kullanılarak her bir satır değerinin ortalaması alınmış ve böylece Tablo $6^{\prime}$ da belirtildiği gibi her kriter için öncelik değeri (ÖD) elde edilmiştir. 
Tablo 6. Kriterlerin Yüzde Ağırlıkları

\begin{tabular}{lllllll}
\hline Kriterler & Fiyat & $\begin{array}{l}\text { Teknik } \\
\text { Yeterlilik }\end{array}$ & Hizmet kalitesi ${ }_{\text {Hizmeti }}^{\text {Tamir }}$ & $\begin{array}{l}\text { Garanti } \\
\text { Politikas1 }\end{array}$ & ÖD \\
\hline Fiyat & 0,541 & 0,617 & 0,527 & 0,429 & 0,364 & $\mathbf{0 , 4 9 6}$ \\
Teknik Yeterlilik & 0,180 & 0,206 & 0,264 & 0,306 & 0,273 & $\mathbf{0 , 2 4 6}$ \\
Hizmet Kalitesi & 0,135 & 0,103 & 0,132 & 0,184 & 0,182 & $\mathbf{0 , 1 4 7}$ \\
Tamir Hizmeti & 0,077 & 0,041 & 0,044 & 0,061 & 0,136 & $\mathbf{0 , 0 7 2}$ \\
Garanti Politikasi & 0,068 & 0,034 & 0,033 & 0,020 & 0,045 & $\mathbf{0 , 0 4 0}$ \\
Toplam & 1 & 1 & 1 & 1 & 1 & \\
\hline
\end{tabular}

Öncelik değerleri fiyat kriteri için 0,496, teknik yeterlilik kriteri için 0,246, hizmet kalitesi için 0,147, tamir hizmeti için 0,072 ve garanti politikası için 0,040 olarak bulunmuştur. Bu durumda en yüksek öncelik değerine sahip kriter fiyat kriteri olup; en düşük öncelik değerine sahip olan ise garanti politikası kriteridir.

Öncelik değerleri bulunduktan sonra karar vericilerin kriterler arasında kıyaslama yaparken tutarlı olup olmadıkları ölçülmüştür. Tutarlılık oranını bulabilmek için öncelikle ATV değeri bulunmuştur. ATV değeri Tablo 5'te verilen karşılaştırma matrisinin sütunları ile her bir öncelik değerleri çarpılıp elde edilen sonuçların satırlar üzerinden toplamı alınarak bulunmuştur. Daha sonra ATV değeri Tablo 7'de gösterildiği gibi kendisine karşıllı gelen öncelik değerlerine bölünmüştür. Elde edilen sonuçların ortalaması alınarak $\lambda$ max değeri bulunmuştur:

$\lambda \max =(5,334+5,305+5,238+5,014+5,075) / 5=(25,976) / 5=5,193$

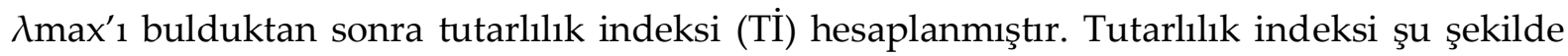
hesaplanmıştır:

$\mathrm{T} \dot{\mathrm{I}}=(\lambda \max -\mathrm{n}) /(\mathrm{n}-1)$

$\mathrm{T} \dot{\mathrm{I}}=(5,193-5) /(5-1)=0,193 / 4=0,048$

Tİ bulunduktan sonra tutarlık oranı hesaplanmıştır. Tutarlılık oranı şu şekilde hesaplanmıştır:

$\mathrm{TO}=\mathrm{TI} / \mathrm{RI}$

$\mathrm{TO}=0,048 / 1.12=0,043$

Rİ değeri Tablo 4'te verilen Rassal İndeks tablosunda n=5'e karşılık gelen 1,12 değeridir. Elde edilen tutarlık oranı 0,10'dan küçük olduğu için yapılan karar verme işlemi tutarlıdır.

Tablo 7. ATV Değeri ve Tutarlılık Oranları

\begin{tabular}{lllllllll}
\hline & Fiyat & $\begin{array}{l}\text { Teknik } \\
\text { Yeterlilik }\end{array}$ & $\begin{array}{l}\text { Hizmet } \\
\text { kalitesi }\end{array}$ & $\begin{array}{l}\text { Tamir } \\
\text { Hizmeti }\end{array}$ & $\begin{array}{l}\text { Garanti } \\
\text { Politikası }\end{array}$ & ÖD & ATV & ATV/ÖD \\
\hline Fiyat & 1,000 & 3,000 & 4,000 & 7,000 & 8,000 & $\mathbf{0 , 4 9 6}$ & 2,646 & 5,334 \\
Teknik Yeterlilik & 0,333 & 1,000 & 2,000 & 5,000 & 6,000 & $\mathbf{0 , 2 4 6}$ & 1,305 & 5,305 \\
Hizmet Kalitesi & 0,250 & 0,500 & 1,000 & 3,000 & 4,000 & $\mathbf{0 , 1 4 7}$ & 0,770 & 5,238 \\
Tamir Hizmeti & 0,142 & 0,200 & 0,333 & 1,000 & 3,000 & $\mathbf{0 , 0 7 2}$ & 0,361 & 5,014 \\
Garanti Politikası & 0,125 & 0,166 & 0,250 & 0,333 & 1,000 & $\mathbf{0 , 0 4 0}$ & 0,203 & 5,075 \\
$\lambda_{\max }=5,193 ;$ Tİ=0,048; TO=0,043 (TO $\leq 0,10$ olduğundan karşılaştırmalar tutarlıdır.) & & \\
\hline
\end{tabular}


Satın alma birimi yöneticisi ve çalışanlarının belirledikleri kriterler doğrultusunda her bir kriter bakımından alternatif medikal firmalar karşılaştırılmıştır. ÖD, ATV değerleri, TO değeri, Tİ değeri ve $\lambda_{\max }$ değeri ikili karşılaştırma matrisinde olduğu gibi hesaplanmıştır. Ancak Rassal İndeks değerinin hesaplanmasında Tablo 4'te verilen Rassal İndeks tablosunda $\mathrm{n}=4^{\prime}$ e karşılık gelen 0.90 değeri dikkate alınarak hesaplama yapılmıştır. Tablo 8, 9, 10, 11, 12 'de görüldüğü gibi tutarlılık oranları 0,10 'dan küçük olduğu için matrisler tutarlı sayılmıştır.

Tablo 8. Medikallerin Fiyat Kriteri Açısından İkili Karşılaştırmaları

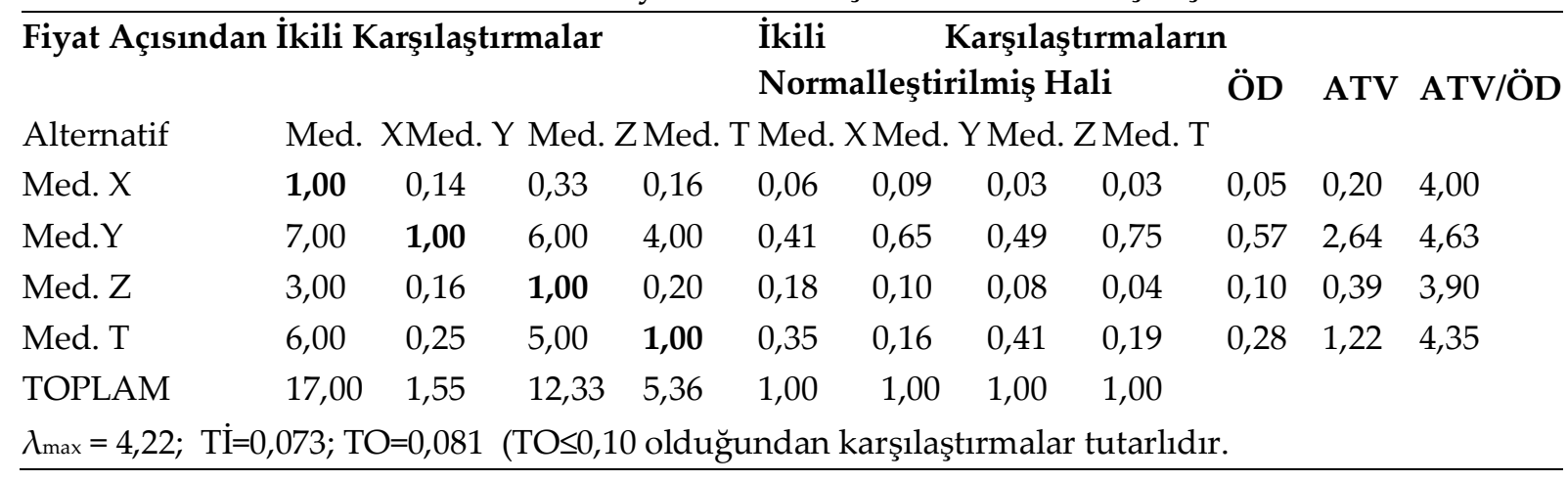

Tablo 8'de verilen ikili karşılaştırmalar matrisinde, fiyat kriteri açısından en yüksek yüzde ağırlığa sahip alternatif medikal firması $Y$ firması ve en düşük yüzde ağırlı̆̆a sahip olan medikal firması $X$ firmasıdır.

Tablo 9. Medikallerin Teknik Yeterlilik Kriteri Açısından İkili Karşılaştırmaları

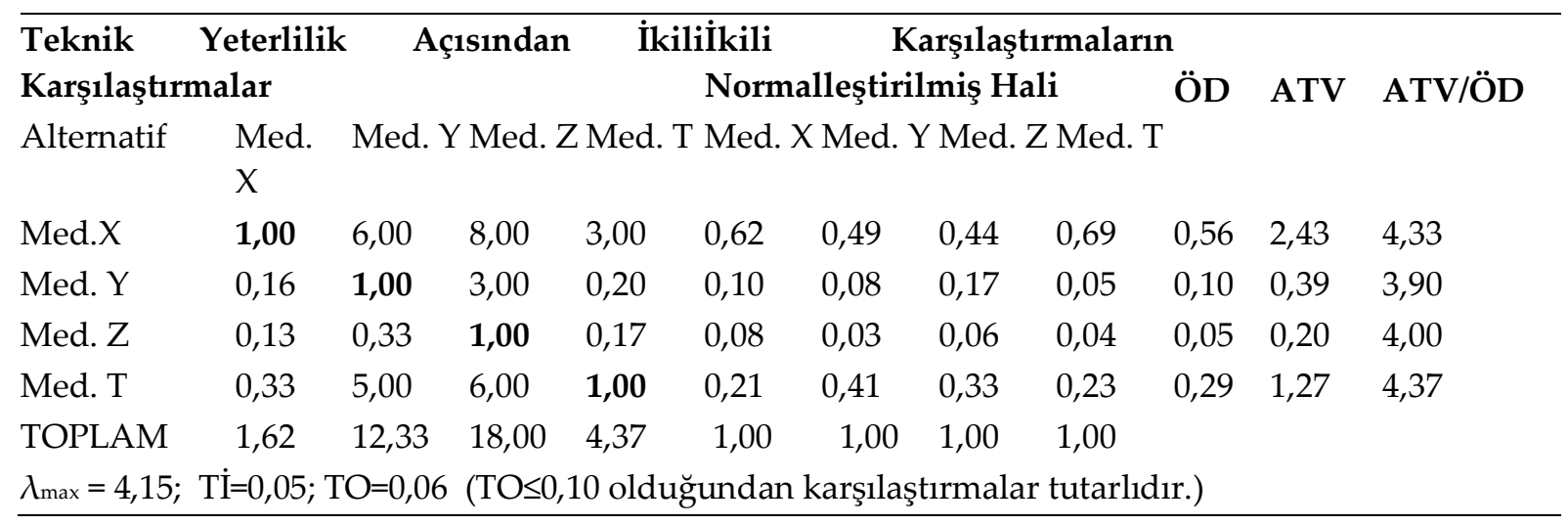

Tablo 9'da verilen ikili karşılaştırmalar matrisinde, teknik yeterlilik kriteri açısından en yüksek yüzde ağırlı̆̆a sahip alternatif medikal firması Medikal X iken en düşük yüzde ağırlığa sahip olan medikal firması Z'dir. 
Tablo 10. Medikallerin Hizmet Kalitesi Kriteri Açısından İkili Karşılaştırmaları

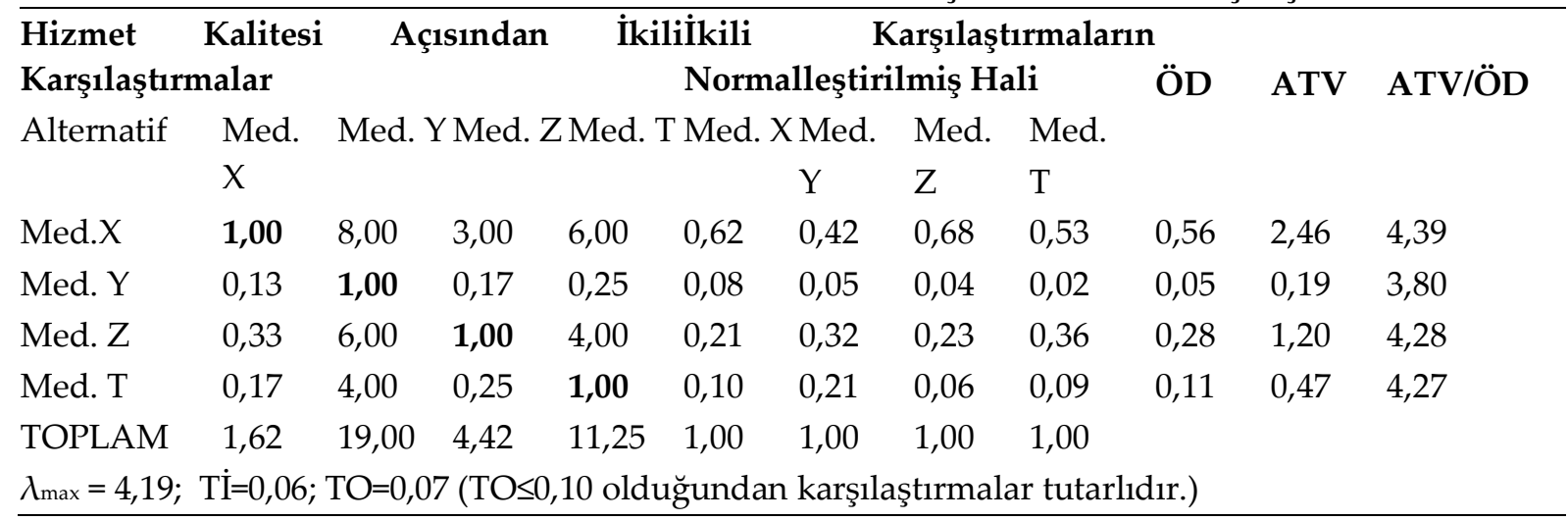

Tablo 10'da verilen ikili karşılaştırmalar matrisinde, hizmet kalitesi kriteri açısından en yüksek yüzde ağırlığa sahip alternatif medikal firması Medikal X ve en düşük yüzde ağırlığa sahip olan medikal firması Medikal Y'dir.

Tablo 11. Medikallerin Tamir Hizmeti Kriteri Açısından İkili Karşılaştırmaları

\begin{tabular}{|c|c|c|c|c|c|c|c|c|c|c|c|}
\hline \multirow{2}{*}{\multicolumn{2}{|c|}{$\begin{array}{l}\text { Tamir Hizmet } \\
\text { Karşılaştırmalar }\end{array}$}} & \multirow{2}{*}{\multicolumn{2}{|c|}{ Açısından }} & \multicolumn{6}{|c|}{ İkiliİkili $\quad$ Karşılaştırmaların } & \multirow{3}{*}{ ATV } & \multirow{3}{*}{ ATV/ÖD } \\
\hline & & & & & \multicolumn{4}{|c|}{ Normalleştirilmiş Hali } & \multirow[t]{2}{*}{ ÖD } & & \\
\hline Alternatif & Med. & XMed. Y & Y Med. Z & Med. T & Med. X & $\begin{array}{l}\text { Med. } \\
\text { Y }\end{array}$ & $\begin{array}{l}\text { Med. } \\
Z\end{array}$ & $\begin{array}{l}\text { Med. } \\
\mathrm{T}\end{array}$ & & & \\
\hline Med.X & 1,00 & 0,14 & 3,00 & 0,20 & 0,08 & 0,09 & 0,17 & 0,04 & 0,09 & 0,37 & 4,11 \\
\hline Med. Y & 7,00 & 1,00 & 8,00 & 4,00 & 0,53 & 0,66 & 0,44 & 0,75 & 0,59 & 2,66 & 4,51 \\
\hline Med. Z & 0,33 & 0,13 & 1,00 & 0,17 & 0,02 & 0,08 & 0,06 & 0,03 & 0,05 & 0,20 & 4,00 \\
\hline Med. T & 5,00 & 0,25 & 6,00 & 1,00 & 0,38 & 0,16 & 0,33 & 0,19 & 0,26 & 1,16 & 4,46 \\
\hline TOPLAM & 13,33 & 1,52 & 18,00 & 5,37 & 1,00 & 1,00 & 1,00 & 1,00 & & & \\
\hline
\end{tabular}

Tablo 11'de verilen ikili karşılaştırmalar matrisinde, tamir hizmeti kriteri açısından en yüksek yüzde ağırlığa sahip alternatif medikal firması Medikal Y ve en düşük yüzde ağırlığa sahip olan medikal firması Medikal Z'dir.

Tablo 12. Medikallerin Garanti Politikası Kriteri Açısından İkili Karşılaştırmaları

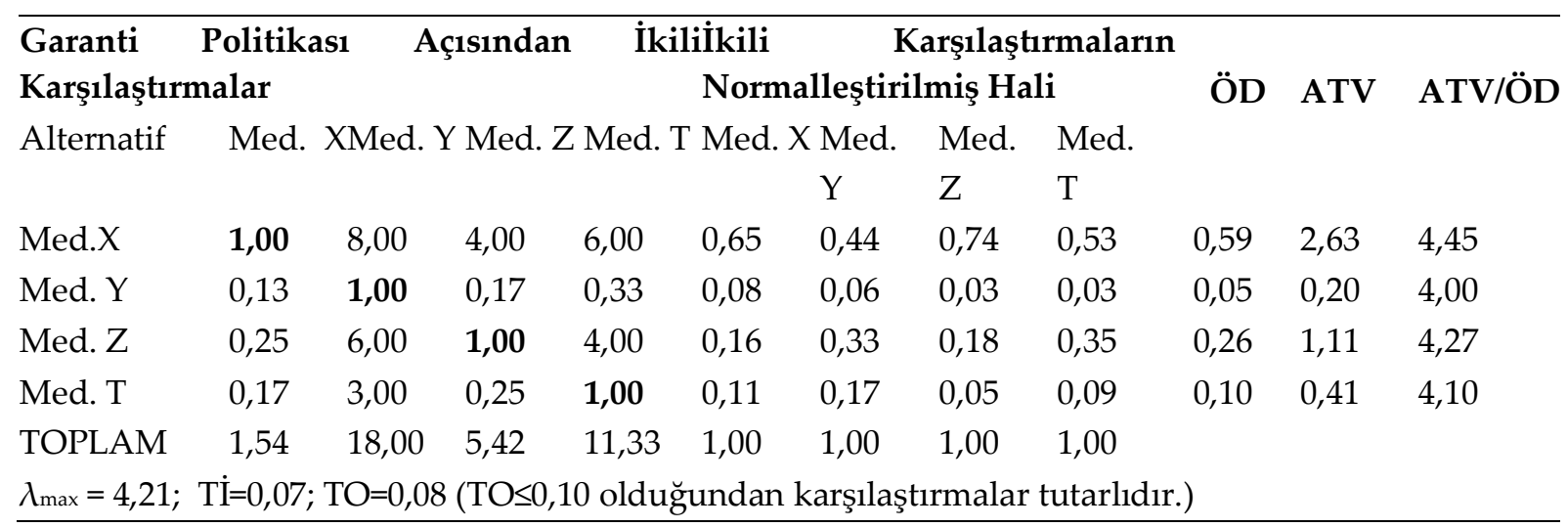


Tablo 12' de verilen ikili karşılaştırmalar matrisinde, garanti politikası kriteri açısından en yüksek yüzde ağırlığa sahip alternatif medikal firması Medikal X ve en düşük yüzde ağırlığa sahip olan medikal firması Medikal Y'dir.

Son aşama nihai öncelik değerlerinin hesaplanmasıdır. Bu aşamada kriterlerin öncelik değerleri ile alternatiflerin öncelik değerleri birebir çarpılmış ve her bir alternatife ait öncelik değeri bulunmuştur. En yüksek değeri alan alternatif, karar problemi için en iyi alternatif olarak belirlenmiştir.

Tablo 13. Alternatiflerin Önceliklerinin Hesaplanması

\begin{tabular}{llllll}
\hline \multirow{2}{*}{ KRITERLER } & Medikal X & Medikal Y & Medikal Z & Medikal T & $\begin{array}{l}\text { KRİTER } \\
\text { ĂĞIRLIĞI }\end{array}$ \\
Fiyat & 0.05 & 0.57 & 0.10 & 0.28 & 0.495 \\
Teknik yeterlilik & 0.56 & 0.10 & 0.05 & 0.29 & 0.246 \\
Hizmet kalitesi & 0.56 & 0.05 & 0.28 & 0.11 & 0.147 \\
Tamir hizmeti & 0.09 & 0.59 & 0.05 & 0.26 & 0.072 \\
Garanti politikas1 & 0.59 & 0.05 & 0.26 & 0.10 & 0.040 \\
Alternatiflerin Öncelik Değeri & $\mathbf{0 . 2 7 4}$ & $\mathbf{0 . 3 5 8}$ & $\mathbf{0 . 1 1 7}$ & $\mathbf{0 . 2 4 9}$ & \\
\hline
\end{tabular}

Medikal X'in öncelik değeri 0.274, Medikal Y'nin öncelik değeri 0.358, Medikal Z'nin öncelik değeri 0.117 , Medikal T'nin öncelik değeri 0.249 'dur. Niğde ilinde faaliyet gösteren medikaller arasından en yüksek öncelik değerine sahip olan Medikal Y seçilmelidir. Alternatiflerin öncelik sırası Medikal Y, Medikal X, Medikal T ve Medikal Z'dir.

\section{Tartışma ve Sonuç}

Sağlık kurumlarına hizmet satın almak için başvuran kişilerin teşhis, tedavi ve muayene işlemlerinde kullanılan medikal malzemeler hayati önem taşımaktadır. Hizmet sunumunda ihtiyaç duyulan bu malzemelerin temininde etkin, doğru ve yerinde kararlar verilmesi gerekmektedir. Sağlık kurumları malzeme tedarikçilerini seçerken aynı zamanda belirli kanun ve yönetmeliklere uygun bir şekilde karar vermek durumundadırlar. Sağlık kurumlarının fazla sayıda tedarikçisi bulunduğundan karar vermek daha da zorlaşmaktadır.

$\mathrm{Bu}$ çalışmanın amacı, çok kriterli karar verme yöntemlerinden biri olan AHP yöntemi yardımıyla Niğde ilinde faaliyet gösteren bir üniversite hastanesinin medikal malzeme tedarikçileri arasından en uygun tedarikçinin seçilmesidir. Bu kapsamda en uygun tedarikçiye karar verebilmek için hastanenin satın alma birim yöneticisi ve çalışanları ile görüşme yapılmış olup onların bilgi ve deneyimlerinden faydalanılmıştır.

Medikal firma tedarikçileri belirlenirken fiyat, teknik yeterlilik, hizmet kalitesi, tamir hizmeti ve garanti politikası kriterleri esas alınmıştır. Çalışmanın sonucunda en yüksek öncelik değerine sahip kriter fiyat kriteri; en düşük öncelik değerine sahip kriter ise garanti politikası kriteri olmuştur. Bu sonuca göre hastanenin medikal tedarikçisini seçerken fiyat odaklı karar verdiği ortaya çıkmıştır. Fiyat kriteri açısından en uygun firma Y Medikal, teknik yeterlilik kriteri açısından X Medikal, hizmet kalitesi kriteri açısından X Medikal, tamir hizmeti kriteri 
açısından Y Medikal ve garanti politikası kriteri açısından X Medikal en uygun medikal olduğu sonucuna varılmıştır. Alternatiflerin kriterler açısından ağırlıklarına bakıldığında $Y$ Medikalin en uygun tedarikçi olarak seçilebileceğine karar verilmiştir.

Bu çalışma sağlık sektörünün en önemli uygulama alanlarından biri olan hastaneler üzerinde yürütülmüsstür. Çalışmanın Niğde ilinde faaliyet gösteren medikaller ile sinırlı tutulması, tedarikçilerin hastanenin en fazla alım yaptığı medikal firmalardan oluşması ve satın alma sorumlularının bakış açısı ile değerlendirilmesi açısından literatürdeki diğer çalışmalardan ayrilmaktadir.

Çalışma, değerlendirme kriterlerini karşılayan ve yalnızca Niğde ilinde faaliyet gösteren toplam 10 adet medikal firma içerisinden hastanenin en sık alım yaptığı 4 medikal firma ile sinırlı tutulmuştur. İleride yapılacak araştırmalarda sağlık kurumunun tedarikçisi olan il dışında faaliyet gösteren firmaların da çalışmaya dâhil edildiği ve kriterlerin çeşitlendiği durumlar için ele alınması düşünülebilir.

\section{Kaynakça}

Adıgüzel, T., Çetintürk, İ., \& Er, O. (2009). Konaklama işletmelerine olan müşteri tercihinin analitik hiyerarşi prosesi yöntemi ile belirlenmesi. Süleyman Demirel Üniversitesi Vizyoner Dergisi, 1(1), 17-35.

Akdeniz, A., \& Turgutlu, T. (2007). Türkiye'de perakende sektöründe analitik hiyerarşik süreç yaklaşımıyla tedarikçi performans değerlendirilmesi. Dokuz Eylül Üniversitesi Sosyal Bilimler Enstitüsü Dergisi, 9(1), 1-17.

Albayrak, E., \& Erensal, Y. (2004). Using analytic hierarchy process (ahp) to improve human performance: an application of multiple criteria decision making problem. Journal of Intelligent Manufacturing, 15(4), 491-503.

Alp, S., \& Gündoğdu, C. (2012). Kuruluş yeri seçiminde analitik hiyerarşi prosesi ve bulanık analitik hiyerarşi prosesi uygulaması. Dokuz Eylül Üniversitesi Sosyal Bilimler Enstitüsü Dergisi, 14(1), 7-25.

Asadi, R., Etemadian, M., Shadpour, P., \& Semnani F. (2018). Designing a model of selection and assessment of hospital outsourcing services based on approach hierarchical possess (AHP) in hospitals. Journal of Hospital, 16(4), 9-18.

Aydın, Ö., Öznehir, S., \& Akçalı, E. (2009). Ankara için optimal hastane yeri seçiminin analitik hiyerarşi süreci ile modellenmesi. Süleyman Demirel Üniversitesi İktisadi ve İdari Bilimler Fakültesi Dergisi, 14(2), 69-86.

Badri, M. (1999). Combining the analytic hierarchy process and goal programming for global facility location-allocation problem. International Journal of Production Economics, 62 (3), 237-248.

Bali, S., \& Amin, S. (2017). An analytical framework for supplier evaluation and selection: a multi-criteria decision making approach. International Journal of Advanced Operations Management, 9(1), 57-72.

Bayar, İ. E. (2008). Kamu hastanelerinde tedarik zinciri yönetimi ve örnek bir uygulama (Yüksek Lisans Tezi, Dokuz Eylül Üniversitesi Sosyal Bilimler Enstitüsü, İzmir). 
Bayhan, M. (2011). Hizmet sektöründe tedarikçi seçiminde bulanık kalite fonksiyon göçerimi kullanımı üzerine bir uygulama (Doktora Tezi, Süleymen Demirel Üniversitesi Sosyal Bilimler Enstitüsü, Isparta).

Byrnes, J. (2004). Fixing the healthcare supply chain. Harvard Business School Working Knowledge https://hbswk.hbs.edu/archive/fixing-the-healthcare-supply-chain

Chou, T. Y., Hsu, C. L., \& Chen, M. C. (2008). A fuzzy multi-criteria decision model for international tourist hotels location selection. International Journal of Hospitality Management, 27(2), 293-301.

Cihan, Ş., Ayan, E., Eren, T., Topal, T., \& Yıldırım, E., (2017). Çok ölçütlü karar verme yöntemleri ile ekokardiyografi cihazı seçiminin yapılması. Sağlık Bilimleri ve Meslekleri Dergisi, 4(1), 41-49.

Çerçeve Anlaşmalar ve Toplu Alımlar Genelgesi (2011), Sayı:3431 http://www.tkhk.gov.tr/828_genelgeler

Dağdeviren, M., \& Eren, T. (2001). Tedarikçi firma seçiminde analitik hiyerarşi prosesi ve 0-1 hedef programlama yöntemlerinin kullanılması. Gazi Üniversitesi Mühendislik Mimarlık Fakültesi Dergisi, 16(2), 41-52.

Dağdeviren, M., Akay, D., Kurt, M. (2004). İş değerlendirme sürecinde analitik hiyerarşi prosesi ve uygulaması. Gazi Üniversitesi Mühendislik Mimarlı Fakültesi Dergisi, 19(2), 131138.

Dağdeviren, M., \& Yüksel, İ. (2008). Developing a fuzzy analytic hierarchy process (AHP) model for behavior-based safety management. Information Sciences, 178(6), 1717-1733.

Davras, G., \& Karaatll, M. (2014). Otel işletmelerinde tedarikçi seçimi sürecinde AHP ve BAHP yöntemlerinin uygulanması. Hacettepe Üniversitesi İktisadi ve İdari Bilimler Fakültesi Dergisi, 32(1), 87-112.

Dickson, G. (1966). An analysis of vendor selection: systems and decisions. Journal of Purchasing, 1(2),5-17.

Doğan, N. Ö., \& Gencan, S. (2013). Seyahat acentası yöneticilerinin bakış açısıyla en uygun otel seçimi: bir analitik hiyerarşi prosesi (AHP) uygulaması. Erciyes Üniversitesi İktisadi ve İdari Bilimler Fakültesi Dergisi, 41, 69-88.

Eleren, A., (2007), Markaların tüketici tercih kriterlerine göre analitik hiyerarşi süreci yöntemi ile değerlendirilmesi: beyaz eşya sektöründe bir uygulama. Yönetim ve Ekonomi Dergisi, 4(2), 47-64.

Gerdsri, N., \& Kocaoğlu, D. (2007). Applying the analytic hierarchy process (AHP) to build a strategic framework for technology roadmapping. Mathematical and Computer Modelling, 46(7-8), 1071-1080.

Ghodsypour, S. H., \& Brien, C. O., (1998). A decision support system for supplier selection using an integrated analytic hierarchy process and linear programming. International Journal of Production Economics, 56(57), 199-212.

Gupta, H. (2015). Selection of best hospital for surgery using ahp. IUP Journal of Operations Management; Hyderabad, 14(3), 18-32. 
Handfield, R., Walton, S., Sroufe, R., \& Melnyk, S. (2002). Applying environmental criteria to supplier assessment: A study in the application of the analytical hierarchy process. European Journal of Operational Research, 141(1), 70-87.

Kamu İhale Kanunu (KİK). (2002). No: 4734. http://www.ihale.gov.tr./Mevzuat.aspx.

Korpela, J., Lehmusvaara, A., \& Tuominen, M. (2001). Customer service based design of the supply chain. International Journal of Production Economics, 69 (2), 193-204.

Kurttila, M., Pesonen, M., Kangas, J., \& Kajanus, M. (2000). Utilizing the analytic hierarchy process AHP in swot analysis a hybrid method and its application to a forest certification case. Forest Policy and Economics, 1, 41-52.

Kuruüzüm, A., \& Atsan, N. (2001). Analitik hiyerarşi yöntemi ve işletmecilik alanındaki uygulamaları. Akdeniz İktisadi İdari Bilimler Dergisi, 1, 83-105.

Lee, Y., \& Kozar, K. (2006). Investigating the effect of website quality on e-business success: An analytic hierarchy process (AHP) approach. Decision Support Systems, 42(3), 13831401.

Malik, M. M., Abdallah, S., \& Hussain, M. (2016). Assessing supplier environmental performance: applying analytical hierarchical process in the united arab emirates healthcare chain. Renewable and Sustainable Energy Reviews, 55(1), 1313-1321.

Manap, G. (2006). Analitik hiyerarşi yaklaşımı ile turizm merkezi seçimi. Ticaret ve Turizm Eğitim Fakültesi Dergisi, 2, 157-170.

Nebol, E. (2016). Tedarik zinciri ve lojistik yönetimi. Ankara: Nobel Yayınc1lık

Ömürbek, N., \& Şimşek, A. (2014). Analitik hiyerarşi süreci ve analitik ağ süreci yöntemleri ile online alışveriş site seçimi. Yönetim ve Ekonomi Araştırmaları Dergisi, 1(22), 306-327.

Özyörük, B., \& Özcan, E. (2008). Analitik hiyerarşi sürecinin tedarikçi seçiminde uygulanması: otomotiv sektöründen bir örnek. Süleyman Demirel Üniversitesi İktisadi ve İdari Bilimler Fakültesi, 13(1), 133-144.

Saaty, T., \& Tran, L. (2007). On the invalidity of fuzzifying numerical judgments in the Analytic Hierarchy Process. Mathematical and Computer Modelling, 46, 962-975.

Sambasivan, M., \& Fe1, N. Y. (2008). Evaluation of critical success factors of implementation of ISO 14001 using analytic hierarchy process (AHP): a case study from Malaysia. Journal of Cleaner Production, 16(3), 1424-1433.

Soba, M. (2014). Banka yeri seçiminin analitik hiyerarşi süreci ve electre metodu ile belirlenmesi: uşak ilçeleri örneği. Mustafa Kemal Üniversitesi Sosyal Bilimler Enstitüsü Dergisi, 11(25), 459-473.

Soner, S., \& Önüt, S. (2006). Çok kriterli tedarikçi seçimi: bir electre-ahp uygulaması. Mühendislik ve Fen Bilimleri Dergisi, 4, 110-120.

Tahriri, F., Osman, R., Ali, A., Yusuff, R., \& Esfandiary, A. (2008). AHP approach for supplier evaluation and selection in a steel manufacturing company. Journal of Industrial Engineering and Management, 1(2), 54-76.

Tengilimoğlu, D., \& Yiğit, V. (2013). Sağllk işletmelerinde tedarik zinciri ve malzeme yönetimi. Ankara: Nobel Yayın 
Toksarı, M. (2007). Analitik hiyerarşi prosesi yaklaşımı kullanılarak mobilya sektörü için ege bölgesi'nde hedef pazarın belirlenmesi. Yönetim ve Ekonomi, 14(1), 171-180.

Uzun, S., \& Kazan, H. (2016). Çok kriterli karar verme yöntemlerinden ahp topsıs ve promethee karşılaştırılması: gemi inşada ana makine seçimi uygulaması. Journal of Transportation and Logistics, 1(1), 100-113.

Vatansever, K. (2013). Kamu hastanelerinde mal alım kararlarının bulanık ahp yöntemiyle değerlendirilmesi ve gediz devlet hastanesi uygulaması. Süleyman Demirel Üniversitesi İktisadi ve İdari Bilimler Fakültesi Dergisi, 18(3), 225-244.

Yadav, A., Bhandari, G., Ergü, D., Ali, M., \& Anis, M. (2015). Supplier selection by ahp in kmc pharmaceutical: use of gmibm method for inconsistency adjustment. Journal of Management Research, 7(5), 19-46.

Yaralığlu, K. (2001). Performans değerlendirmede analitik hiyerarşi prosesi. Dokuz Eylül Üniversitesi İktisadi ve İdari Bilimler Dergisi, 16(1), 129-142.

Yenersoy, G. (1990). Malzeme yönetim sistemleri. İstanbul: MA-PA Yayınları

Wong, J., \& Li, H. (2008). Application of the analytic hierarchy process (AHP) in multicriteria analysis of the selection of intelligent building systems. Building and Environment, 43(1), 108-12. 